\title{
SØLVKLAR TÅGE
}

\author{
i spejlet Bag Spejlet
}

\section{André Wang Hansen}

\section{Alice keder sig!}

Hun har leget, tiden går trægt, rummets muligheder er for længst udtømt. Hun døser. Og håber, at et eller andet uventet vil ske, der kan vende den negativesituation til en positiv.

Alice gaber!

Og som Benjamin lidt indadvendt har noteret sig, åbner mennesket sig i sin gaben som en afgrund: det forsøger at ligne den kedsomhed, der omgiver det.

Alice falder hen!

I sin døs bliver hun klar over spejlets muligheder. Det sker i et ganske kort glimt, der ligner dét, Breton havde i øjnene, da den surrealistiske erkendelse åbenbaredes for ham. Dog var det ikke et spejl, men et vindue som transparens og samtidig uigennemtrængelighed, der satte den Breton'ske tankeflugt i gang.

Det uventede sker!

Mens Alice falder hen, falder hun også ned og igennem sin egen afgrund. Hun oplever pludselig at være i en anden verden, hvor alt ikke bare kan ske men faktisk sker. Som Breton 'ser' hun på sin bevidsthed 'indefra'. Og som Benjamin tager hun konsekvensen af det ændrede syn ved at gøre det til genstand for en (øjeåbnende) undersøgelse.

Alice drømmer? 
Det oplevede indgår i nye forbindelser, kalaidoskopisk og surrealistisk, endda førend surrealismen var opfundet. Konkret tid og rum opløses i fragmenter, der bestandigt kan danne nye mønstre af mening, ugidelighedens passivitet forvandler sig til fantasifuld aktivitet, mens Alice dematerialiserer sig og svæver igennem spejlets sølvklare tåge.

2

Scenen er indledningskapitelt fra en børnebog, klassikeren af Lewis Carroll: Bag Spejlet (Through the Looking Glass) fra 1872. Skønt ren fiktionsfigur er, eller rettere var, Alice virkelig nok. Ingen $\mathrm{Na}-$ dia, ganske vidst, men dog 'muse' og objekt for huslæreren, matematikeren og amatørfotografen Lewis Carroll's ustyrlige og umulige begær, der således i stærkt sublimeret form blev æsteticeret og formaliseret i fascinerende, fantastiske fortællinger. Og lidt ulækre Lolita-skildringer i fotografiets medium.

Spejlinger foregår på uendelig mange planer i Bag Spejlet, hvor metafysikken imidlertid holdes i skak af en helt absurd matematisk logik, der kun kan tænkes i et mørkekammer.

Vi møder Alice i en tilstand mellem vågen og drøm. Der er sket noget, der sker noget og mere vil ske. Mens Alice langsomt falder hen rekapitulerer hun hvad der allerede er sket, i form af en tyst 'dialog' med en umælende sort killing, der har samme funktion som en boksebold og en sparringspartner - og en bamse.

Alice har spillet skak med sin søster. Og tabt. Fordi hun overså springerens 'kvantespring'. Spillet aktiverer erindringen om en anderledes skakleg med søsteren fra foregårende dag, et rollespil, som søsteren forholdt sig alt for 'realistisk' til. Alice har kigget ud af vinduet og set en dreng, der var i færd med at lave et bål udenfor. Det sner, er koldt, men Alice noterer at sneen som dække kan være varm. Som bålet. Eller et kys, føjer Carroll til.

Alice har også kigget på katten Dina, der først har 'vasket' den sorte killing, Kitty, og som er i gang med den hvide killing, Snehvide, mens Alice 'konverserer' Kitty.

Den sorte killing bliver indirekte anledning til, at Alice bliver opmærksom på spejlet. Inspireret af killingens blødhed, forestiller hun sig at spejlet er blødt som et slør fremfor en hård, uigennemtrængelig flade. Hun løfter, i overført betydning, sløret og træder simpelthen igennem spejlet og opdager dér på den anden side, at spejlets stue er fuldstændig identisk med og akkurat lige så kedelig som den 'rigtige' stue, i hvert fald hvad angår det, hun tidligere har set $i$ spejlet. Men heldigvis er der meget mere, og det er spændende og anderledes: det skrevne ord er tgileåtsrofu, billederne på væggen virker levende og skakbrikkerne er vitterlig 'levende'. I hvert fald spadserer de rundt, to og to, en del af dem, i den spejlede kamins aske.

Pludselig udspiller der sig et drama for øjnene af Alice: Det hun før ventede på: den kedsommelige passivitets håb om at der vil ske noget. Nu kan Alice ikke nøjes med at se på, hun griber bogstavelig talt ind i dramaet eller historiens gang: en hvid skakbonde skriger og vælter omkuld oppe på bordet (hvor skakspillet befandt sig førend Alice blev misfornøjet). Den hvide dronning iler til undsætning, men vælter i sit hastværk sin husbond, den hvide konge, omkuld i asken. Da det imidlertid tager sin tid for dronningen at komme fra asken til ilden, gribe Alice ind og løfter dronningen - til stor bestyrtelse op, og lidt senere 'hjælper' hun - lidt mere forsigtigt, men med samme bestyrtelse til følge - den hvide konge op på bordet til den stakkels bonde.

Dronningens og kongens bestyrtelse skyldes, at de ikke kan se Alice, som kan se og høre dem. Bestyrtelsen bevirker, at kongen må nedfælde sin oplevelse på skrift (for ikke at glemme den) i en stor notesbog. Også her kan Alice ikke dy sig for at gribe ind, hun fører hans pen og skriver i stedet for om kongens 'spring' om Springeren, der tidligere har irriteret hende.

Ved at skrive bliver hun opmærksom på en bog med en ganske mystisk skrift, som hun først efter grundig overvejelse finder ud af kun kan læses v.h.a. et spejl. Selvom spejlet formår hende til at se skrifttegnene i rette sammenhæng, fremstår det skrevne umiddelbart mystisk. Hør blot:

Et slidigt gravben vridrede

$i$ brumingen på tidvis plent,

og lappingen var vaklig, of

det borte grøfgrin grent.

Efter at have funderet endnu en gang over sagens rette sammenhæng, begiver Alice sig længere ind i spejlhuset. Her forlader vi hendé.

Af dette handlingsreferat er vel fremgået, at en relativ høj grad af symmetri præger kapitlets tematiske univers. Dog er der tale om en ganske særlig form for symmetri, hvor etableringen af identiteter lige så hurtigt opløses i forskelle, der imidlertid medieres igen, o.s.v. 
Glidninger er kodeordet og den paradigmatiske struktur for fortællingen.

Tag f.eks. fortællingens rum:

Der er strengt taget tale om to rum, et indenfor og et udenfor, men forbundet med hinanden igennem et vindue. Rummene spejler hin anden for så vidt som Alice indenfor kigger på en dreng udenfor; hans bål udenfor reflekterer hendes kaminild indenfor. Rumforholdet ændrer sig imidlertid i det øjeblik Alice gentager sit blik ud af vinduet i spejlet, som hun derpå forcerer, hvorved det, der før var indenfor, altså stuen, nu bliver udenfor, set fra Alice's synsvinkel. Det her er svært at håndtere. For kan man ikke også sige, at det rent faktisk er Alice, der er udenfor? I drømmen har rum ingen grænser. Og dog er den drømmende lokaliserbar.

5

Historiens aktører indgår i tilsvarende, ret komplicerede relationer af identiteter og forskelle, hvor skakspillet umiddelbart fremstår som planimetrisk ramme, i først omgang hvad angår den binære opposition sort/hvid, i anden omgang hvad angår aktørernes, altså 'brikkernes' rang eller dominans inden for en fikseret sfære.

Spørgsmålet er imidlertid, om det er så 'fladt' som så?

Umiddelbart kan man, med Alice's optik, se kattene som brikker i et spil skak. Vi har hvid (Snehvide, for at det ikke skal være løgn) versus sort (Kitty), begge killinger med status som 'bønder' i forhold til moderen Dina, der har en dronnings beføjelser. Det misforhold skulle egentlig være klart nok, hvis det ikke var fordi kattefamiliens 'roller' blandede sig med Alice's og søsterens 'roller' samt 'skakfamiliens', hvorved det bliver som et spil skak, hvor blot en enkelt bevægelse, et træk forvandler hele stillingen.

Dog kan man ikke sige, at spillets regler bliver fulgt særligt nøjeregnende. Det er trækkene i sig selv, bevægeligheden inden for en given ramme, det drejer sig om. Lad os se på et par eksempler på forandringer eller glidninger.

Indledningsvis 'vasker' katten Dina den hvide killing, ganske respektløst. Afslutningsvis i første kapitel overtager mennesket Alice kattens Dina's position som overordnet, da hun 'vasker' eller soignerer den hvide skakkonge, lige så respektløst. I begge tilfælde sættes 'den anden' ud af spillet. Forholdet: Dina (dronning) og Snehvide (bonde) gentages strukturelt hos Alice (dronning) og den sorte killing (bonde), senere i hendes behandling af den hvide konge (nu: bonde), hvorved skakspillets højst rangerende brik bliver til den lavest rangerende.

Den 'rigtige' dronning falder ind i inversionstemaet: Affabelt be- nævner hun den væltede hvide bonde for sin 'kejserlige killing', i øvigt lige forinden hun kommer til at vælte den hvide konge omkuld, der også således kommer til at dele skæbne og status med den stakkels bonde.

Stakkels mand, kunne man sige, med en vis gyldighed for hele historien, hvor forfatteren Lewis Carroll omfunktionerer sit faktiske begær i en sådan grad, at den 'mandlige' logik i skakspillet bliver helt usynlig.

Skakdronningen undergår også forvandling. Faktisk bliver hun til en kattekilling, hvor Alice løfter hende op mod hendes vilje. De 'rigtige' killinger, Kitty og Snehvide, er nok brikker i et spil, de fungerer dog også som 'billeder' på Alice og søsteren, hvor katten Dina's rolle tilsvarer 'de voksne', som vi ganske betegnende ikke hører videre til.

Det forudsigelige er kedeligt.

Derfor gør Alice samtidig killingen Kitty til sin 'søster' og sit 'barn'. Det er sjovt at spille.

I Alice's dagdrøm bearbejdes dagsresterne ganske effektivt og på en måde, hvor reale negative oplevelser vendes til - surrealistiske positive oplevelser. En lille fin pointe er her Alice's afstrafning af springeren, der tidligere bevirkede at hun tabte et spil skak med søsteren: hun giver den en veritabel nedtur, og bekræfter straffen ved at formulere den på skrift. Sådan! Som nævnt til den hvide konges forvirring, der ikke aner, hvad det drejer sig om

Det gør vi, ikke sandt? Spring ud i det!

Skakspillet og dets mærkværdige logik i Bag spejlet kunne fratage opmærksomheden fra det andet sort/hvide spil, der spiller en lige så stor, men bogstavelig talt mere tåget rolle for det fantastiske univers, nemlig fotografen Lewis Carroll's egen fascination af den fotografiske teknik og omvendelsesproceduren fra negativ til positiv. $\mathrm{Nu}$ var det ikke et spejlreflekskamera, som Lewis Carroll benyttede til at udødeliggøre Alice, når han ikke skrev historier om hende. Den dengang mere primitive teknologi var imidlertid fuldt tilstrækkelig for fotografen Carroll til at reflekterer fotografiets karakteristiske spejling af virkeligheden, hvor vrangen så at sige først måtte vendes ud (negativ) førend ret kunne blive ret og alt sat på plads (positiv). Det er den proces, som vi i litterær form oplever i både Alice $i$ eventyrland og Bas spejlet.

For fotografen er negativet som bekendt 'positivt', hvor alle andre opfatter det egentligt negativit. Uden ordentligt negativt arbejde bliver positivet 'dårligt', altså negativt 
Bag spejlet er et fotografisk eventyr.

Det er dog ikke konstrueret over en simpel sort/hvid eller negativ/ positiv opposition (som historiens sepjlvendinger umiddelbart kunne give anledning til at tro), det er snarere mellemrummet eller den forbindende instans mellem negativ og positiv, der står i centrum, i spejlingen, glidningerne eller i kort form, dialektikken i foretagenet.

Når Lewis Carroll således beskriver forudsætningen for Alice's overgang fra den 'virkelige' til den fantastiske verden som spejlets opløsning i en "sølvklar tåge", refererer han faktisk direkte til det fysisk/kemiske grundlag for dannelsen af det fotografiske billede (sølvkorn i emulsion), indirekte foregriber han Kracauer's bestemmelse af erindringsbilledets dæmoniske dobbelttydighed i dennes metafor for det fotografiske spejlbillede: "mat som et mælkeglas". Og netop Kracauer's videre betragtning, at billedet først bliver gennemsigteligt efterhånden som erkendelsen oplyser sjælens vegeteren og begrænser naturtvangen, belyser på mere end én måde billeddannelsen bag spejlet, hvor læseren så at sige tager del i en erkendelsesproces med Alice som guide.

En børnebogsfigur, en fotografiglad huslærer - og Kracauer, Benjamin og Breton, det er næsten ved at blive blæst for meget op!

Måske. Se i spejlet!

Ikke desto mindre skal også Antonioni inddrages, eller rettere hans film Blow Up, der fra en helt anden vinkel oplyser billeddannelsen Bag Spejlet: ved intensiv betragtning af det fotografiske spejlbillede af virkeligheden opstår muligheden for at opdage mere end hvad der rent faktisk blev set 'i virkeligheden'. Om det så er sandt eller falsk er af en mindre betydning.

I første del af indledningskapitlet til Bag Spejlet 'ser' vi Alice ganske normalt', d.v.s. vi registerer hende og hendes bevægelser, men i den proces overses faktisk samtidig en hel del, fordi øjeblikkenes hastighed uvægerligt kræver prioriteringer af væsentligt og uvæsentligt i situationen, hvor det mindre væsentlige simpelthen 'holdes ude', fortrænges. I anden del af kapitlet, hvor vi tager del i Alice's fantasirejse, 'ser' vi på en anden måde: vi ser på begivenhederne som når vi intensivt betragter et fotografi af begivenhederne. Der er tale om en forlænget og intensiveret betragtning af det øjeblikkelige, hvor det bliver muligt at opdage de små detaljer og nuanceringer, der måtte 'holdes ude' og fortrænges 'i virkeligheden'. På fotografiet er det muligt at stoppe op og gå på opdagelse i det sete, da tiden her er sat ud af kraft.
Det er det, som Carroll, Antonioni, Breton, Benjamin og Kracauer hver på sin vis har opdaget: Carroll udnytter sine fotografiske erfaringer som litterært greb, Breton omsætter erkendelsen i et helt surrealistisk manifest, som fototeoretikerne Benjamin og Kracauer vender yderligere en omgang i deres skarpsindige analyser af den moderne kultur og det fotografiske bliks dialektik af indsigt og udsigt.

Når spejlet på væggen kan blive til et tryllespejl, kan fotografiet i teorien vel også blive til poesi. Under alle omstændigheder fungerer netop digtet, der afslutter første kapitel i Bag Spejlet, som endnu en spejling: det ligner jo (og lyder som) et 'rigtigt' eller 'virkeligt' digt, lige som fotografiet ligner virkeligheden.

Formelt set er alt i orden: "Et slidigt gravben vridrede", men hvad er meningen?

Den er god nok fortæller Klumpe-Dumpe senere i beretningen om Alice. Men for at se den, er det nødvendigt at tænke fotografisk altså at opløse og sætte sammen, fremkalde betydning ud af partikler, tænke 'pars pro toto'. Man skal bare forestille sig en slimet og smidig mellemting af en gravhund og et firben, der bevæger sig som et vridbor, altså vridrer, på pladsen og plænen omkring soluret, der jo viser tiden, når skumringen falder på, for så bruner man jo middagsmaden og ilden brummer under gryderne..., så er det ingen sag at forstå digtet!

Dog. Det handler egentlig slet ikke om at forstå digtet. Det fungerer som alt andet i Bag Spejlet som anledning til dannelsen af nye fantasifulde tankemønstre, hvor processerne er langt vigtigere end resultaterne. Og således også her.

Klik, sagde det, da Alice knaldede brikkerne i og fantasien fløj gennem spejlets sølvklare tåge.

Lad os alle gabe. 